\title{
Drama as a Source of Job Creation in Nigeria: An Example of Emmy Unuja Idegu's the Legendary Inikpi
}

\author{
Mohammed Attai Yakubu (Ph.D)
}

Department of English and Literary Studies, Kogi State University, Anyigba, Kogi State, Nigeria; attaimy@gmail.com

Doi:10.5901/ajis.2015.v4n3p79

\section{Abstract}

There are potentials that abound in Nigeria which are yet to be explored and tapped. Dramatic presentation project using talented youths is an example of these. This paper seeks to discover that jobless youths should be recruited and trained by government agencies and interested companies to dramatise myths, legends, or folktales and other dramatic works as well as government programmes at various locations in the country. Such presentations will attract a large audience. It will provide jobs for youths, enlighten the people, and generate revenue for the government. Furthermore, it will reduce criminal activities as the number of unemployed youths will reduce.

Keywords: Drama, Job creation, Idegu, Legend, Myth, Entertainment.

\section{Introduction}

Nigeria, as a developing country like other developing nations is facing the problem of creating jobs for its youths. Yearly, university graduates, Higher National Diploma (HND), National Diploma (ND), and Nigeria Certificate in Education (NCE) holders are being thrown into the labour market with little or no hope of securing jobs. This has caused many people so much psychological trauma and depression. Out of frustration, some youths have made themselves available for unscrupulous politicians to be used as thugs during elections. Others have taken to armed robbery and other criminal activities while some ladies see prostitution as a means of livelihood. These are very serious social problems that need prompt solutions. It is a solution to this naughty problem of unemployment that this paper seeks to provide.

One of the functions of drama is to provide entertainment. As noted by Agoro (2001),

During the Elizabethan times drama was primarily for entertainment. People wrote plays for the acting companies and made fortunes out of them... Amusement was then the sole function of drama. Drama was business then and those who practised went into it for that purpose.

Thus through its entertainment function, drama creates jobs for people. This is an opportunity that should be utilized in Nigeria. Drama has many functions. It is vibrant and dynamic. As observed by Barranger (2002), "As we sit in the audience, we constitute a human community - a collective presence - as we laugh, cry, enjoy, and applaud". This opportunity provided by drama is not utilised in many parts of Nigeria. This is because of little presence of theatre.

In Nigeria, performance in public arenas is not given attention. The major source of entertainment is the video or DVD player especially in urban areas. In the rural areas, due to poor financial condition and illiteracy, only few people can afford video and television sets, that is where there is electricity. Dramatic presentation is a project that this paper sees as a source of job creation for youths. We believe that with human and material resources, dramatic presentation in public arenas will be a successful venture in Nigeria. It will provide entertainment for the people, generate revenue for the government and individuals involved in the project and provide employment for youths.

The objective of this study is to analyse Idegu's The Legendary Inikpi and point out ways that similar dramatic works in Nigeria can be galvanized for job creation. Moreover, this study is significant in a number of ways as it show cases the potentials that abound in myths, legends, and dramatic works in Nigeria which can be harnessed for youth employment.

The Legendary Inikpi By Emmy I. Idegu is an example of a play that can attract a large number of spectators when performed in Igala land in Kogi State, Nigeria. Igala people are in love with the memory of Inikpi, a Princess who was sacrificed to save the Igala Kingdom from her enemies. Many people have named their daughters after Inikpi and they would like to see the enactment of her story on the stage.

African societies are rich in legends, myths and folktales. Legends and myths are highly valued in the societies where they are told. Many African writers have used them as source materials for written literature. Stories of kings, 
queens, and heroic deeds of great men whether written or existing in the oral tradition of the people when dramatized will be an interesting drama that will attract a large audience. Depending on the audience, the drama may be in the native language, Nigerian Pidgin or the English Language.

\section{Research Design and Methodology}

This research draws primarily from archetypal criticism which denotes recurrent narrative designs, patterns of action, character types, themes, and images which are identifiable in a wide variety of works of literature, as well as in myths, dreams, and even social rituals....An important antecedent of the literary theory of the archetype was the treatment of myth by a group of comparative anthropologists at Cambridge University, especially James G. Frazer, whose The Golden Bough (1890-1915) identified elemental patterns of myth and ritual that, he claimed, recur in the legends and ceremonials of diverse and farflung cultures and religions (Abrams, (c) 2005).

The story of Inikpi or any myth or legend is an example of archetype. Inikpi was a heroine of Igala land and she was an embodiment of courage, virtues, and patriotism. She is a model to many people in Igala land who have named their daughters after her. The story of Inikpi is familiar to every Igala son and daughter and it elicits profound response ( Abrams, (c) 2005) from them. Any popular or traditional story as hypothesized in this study is a potential source of job creation in Nigeria. Archetypal criticism is suitable to this study because of its concern with myths, and legends.

The study sample for this research is Emmy Unuja Idegu's The Legendary Inikpi which is an enactment of Inikpi legend; a story that when dramatised will attract a large audience of viewers in Igala land. In the opinion of the researcher, enactment of myths, legends, and traditional stories is a lucrative venture in Nigeria.

\section{Drama as a Source of Job Creation}

Nigeria is a country that has many rural areas. Many of these rural areas have no electricity therefore, recreational facilities are often in scarce supply. Thus, many people (adults and youths) tend to gather in groups under trees, in sheds, or on verandas to while away the time in conversations. Entertainment in most rural areas occur during festivals and ceremonies such as new yam festival, initiation ceremony, wedding, naming, Christmas, Sallah and other religious festivals. The boredom experienced in rural areas should galvanize dramatic performance for the steady entertainment of the people all year round.

In other words, in Nigeria as a developing country, it is the social responsibility of the government to provide jobs for the citizenry as well as recreational facilities for their relaxation. These are an obligation that every responsible and responsive government should think of carrying out. The government should make life comfortable for the people and be concerned with their welfare. Through theatre, the government can empower youths and improve their standard of living.

According to Cohen (2003), "Theatre is a principal occupation of its practitioners. It is a vocation for professional and an avocation for amateurs, yet in either case theatre is work".

Drama is a companion term of theatre which means something is done, an action is witnessed (Cohen, 2003). Drama can provide an occupation for the unemployed youths in Nigeria.

To use drama as a source of job creation in Nigeria, all the three tiers of government should be involved. That is the federal government, the state and the local government. The ministry of youths, sports and culture can shoulder this responsibility effectively. Each local government of the federation should be made to establish at least three (3) dramatic troupes. Each troupe will have a number of actors and actresses.

The troupes should perform at different public arenas in the local government on rotational basis to avoid monotony of contact between the audience, and actors and actresses. The themes of the performance should be varied to also avoid monotony and redundancy. This will sustain the interest of the audience in the performances.

In the rural and urban areas, there are public buildings such as town halls and school assembly halls that can be used for the performances. Or in Peter Book's term an empty space. The ancient Greek Theatron was probably nothing but a flat circle where performer chanted and danced before a hillside of seated spectators (Cohen 2003). Cohen goes ahead to say that "the minimal requirement for a theatre building is nothing but a place to act and a place to watch." So, a modest structure with stage, seats and scenery construction will serve the purpose of this dramatic presentation project.

In all the arenas, affordable gate fees should be charged. The fees can vary depending on the theme of the drama. Through dramatic performance, the people can be enlightened on government programmes, policies, and activities. These can bring about national development and enhance nation building. People's lives can be changed positively. This project can introduce dynamism into lives in the rural areas. Because as noted by Barranger (2002), the "seeing place or 
theatre is where we are entertained and learn about ourselves and others. It is the place where we perceive the how, the what and the way of our humanness in company of others". Drama entertains and educates, and transforms the society positively. It brings excitement and makes life enjoyable. Dramatic presentation project will make people like rural communities and will minimize rural urban drift which we experience in Nigeria.

\section{Legends, Myths and Folktales in African Societies}

Legends, myths and folktales are traditional stories that exist and are being told in many African communities. The stories may be true or invented but the people see them as authentic. They are meant to entertain, educate and teach moral lessons. These stories are sources of interesting drama. Dramatization of legends and myths is as old as drama itself. As observed in Nigeria Certificate in Education, Course Book on English Language Cycle 4, Module 14, (2000) "The tragedians (Aeschylus, Sophocles and Euripides) who wrote plays for competition at the festival used themes based on Greek myths and legends". Myths, legends, and folktales abound in African societies. They can be performed for people to see. A good example is the Ozidi Saga of ljaw people in Niger Delta transmuted into written drama by J.P. Clark. The story, according to Isidore Okpewho (1998) is,

... a posthumously born hero, who avenges the assassination of his father by fellow-warriors and never stops his slaughter until he eliminates all the forces in his community and reigns in uncontested supremacy, is traditionally told during a festival among the Tarakiri Orua, a sub-group of the ljo of the Nigeria Delta.

Myths like legends are usually told in the day time and at solemn occasions like funerals. It is also told during naming ceremonies. (Yakubu 2010). There is no African society that does not have myths and legend. Most of these have now become subjects of archives.

Myths, Legends, and folktales are vehicles for the preservation and transmission of culture from generations to generations. Thus they are important in African communities and they are valued by the people. Marshall as quoted by Ogunyemi (1987) "remarked that legends and myths are aspects of culture which make for strength". He further states that "myth is a powerful medium of cultural transmission". In every community in Africa, there are myths and legends.

J.P. Clark's Ozidi which is an adaptation of Ozidi saga has been performed severally. When performed in Ibadan, a place that is several kilometres away from the traditional home of the story:

...there were a number of Europeans and other non-ljo colleagues who accompanied Clark to the event, the audience was essentially made up of ljo residents at Ibadan; the performance itself was hosted by Madam Yakubu, an ljo matron... (Okpewho 1998).

Apart from modem issues that may be used as subjects of dramatic works for performances at various locations in Nigeria, traditional stories which people know can attract a large audience when performed on the stage as proved by ljaw residents in Ibadan who came out to see the performance of the Ozidi Saga. As a story in the Niger Delta which the people know, they would like to watch the Ozidi saga. At different locations in Nigeria, performances such as the Ozidi Saga, Moremi myth of lle-Ife, the legend of Bayyagida, Inikpi of Igala Kingdom, etc will be an interesting drama.

A number of African writers use myths and legends as the raw materials for their written works. As noted by Gbilekaa (1997) "Osofisan like Soyinka uses myth to explain happenings in everyday life in their society". Such stories when enacted on the stage will attract and interest the people. Myths and legends are stories that people know and cherish so, they will like to see the live performance on the stage.

\section{Emmy Unuja Idegu's The Legendary Inikpi}

The play, The Legendary Inikpi is an adaptation of a legend in Igala land of Kogi State, Nigeria. Inikpi was a princess who was sacrificed for victory in a war between the Igala people of the present Kogi State, Nigeria and Bini people of the present Edo State, Nigeria as well. The event occurred in the early $16^{\text {th }}$ century. The play, The Legendary Inikpi is a compendium of the tradition of Igala people and their royalty. Apart from being an adaptation of the legend of Inikpi, the play embodies Marxist ideology with its revolutionary impetus. This is in agreement with Ogunyemi's (1987) view that: "Myth can become interwoven with ideology as the author makes use of legends that underscore a preferable way of life".

The Legendary Inikpi when performed in any part of Igala land will attract a large audience across creed, class, and status. On the play, The Legendary Inikpi, Obafemi (2005) says: 
The artistic ingenuity in bringing to contemporary relevance a past that at some level is archaic, yet at other levels is residual and thus relevant to our present socio-political realities converge to yield the beauty in the use of historical materials for creative writing.

The legend of Inikpi has educational, social, cultural, and political significance. The play, apart from its entertainment function, has other functions. It preserves the culture of the people and educates on the needs for patriotism. According to Agoro (2001) "drama is a dynamic agent for advocating social and economic reforms and for projecting and preserving the culture of a people". Plays with the theme of culture are a reservoir of the culture of the people.

Besides, playwrights have used their plays as an agent of change. Inikpi is an embodiment of selfless service. She offered herself for live burial as a sacrifice to save her people from an impending war. The lesson in that is patriotism. So, apart from entertaining the audience, The Legendary Inikpi, if packaged for the proposed dramatic presentation project will teach them to be patriotic citizens. Community theatre has a similar purpose, that is "for promoting developmental issues in a range of circumstances across the country" (Nigeria Certificate in Education, Course Book on English Language, Cycle 4, Module 14, 2000). This dramatic presentation project should be exploited for sustainable development in Nigeria.

Interested graduates and other unemployed youths should be recruited and trained by the ministry vested with the responsibility for the performance at various locations in the country. This is a project that will create jobs for youths, entertain the people, enlighten them and generate revenue for the government. The employment opportunity that will be provided will reduce criminal activities in the country thereby leading to sustainable development.

\section{Findings/Conclusion}

Dramatization of myths, legends, and folktales will promote African culture. It provides the link between present and past. It will enlighten the people on government policies and programmes. Myths and legends are valued in African societies so, dramatizing them can attract a large audience. Actors will be happy to impersonate characters in African myths and legends because these characters are heroes and heroines in the various communities where the legends exist. The audience too, will be happy to see the performance. Dramatization of myth and legends will enable people to have a firm grip of their past. Apart from job creation, this dramatic presentation project has a lot of advantages. Therefore both the government and private sector should consider setting up the machinery for its actualization.

\section{References}

Idegu, E.I. (2005) The legendary Inikpi. Kaduna: T.W. Press Publishers.

Abrams, M. H. ( $\odot 2005$ ) A glossary of literary terms. Boston: Thompson Wordsworth Classics.

Agoro, S.N.A (2001). Theatre and drama in education. Ibadan: Caltop Publications (Nigeria) Limited.

Barranger, M.S. (2002). Theatre, a way of seeing. $5^{\text {th }}$ edition. Belmont: Wadsworth/Thomson Learning.

Gbilekaa, S. (1997). Radical theatre in Nigeria. Ibadan: Caltop Publications (Nigeria) Limited.

Nigeria Certificate in Education (NCE/DLS), Course Book on English Language, cycle 4, module 14, (2000). Kaduna: National Teachers' Institute.

Cohen, R. (2003). Theatre. $6^{\text {th }}$ edition. Boston: McGraw-Hill Higher Education.

Obafemi, O. (2005). Foreward: The legendary Inikpi. Emmy Unuja Idegu. Kaduna: T.W. Publishers.

Ogunyemi, C.O. (1987). "The Communication of legends and myths in Afro-American Literature: a study of Marshall's and Morison's Juju" In Solomon O. Unoh (Eds). Topical Issues in Communication Arts. Uyo: Modern Business Press.

Okpewho, I. (ed) (1998). The oral performance in Africa. Ibadan: Spectrum Books Limited.

Yakubu, M.A. (2010). Communicating in English for tertiary institutions. Lokoja: Mandate Publications. 